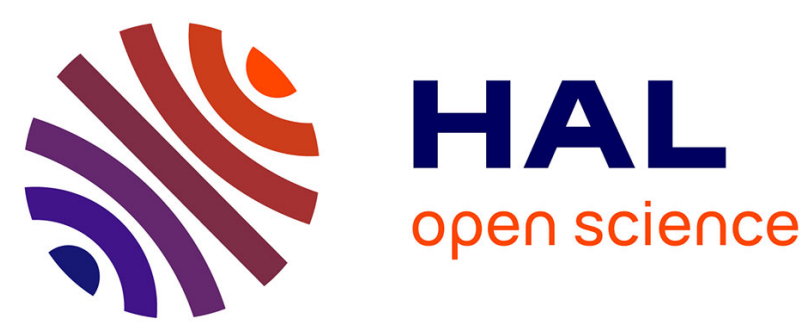

\title{
Growth Hormone (GH1) Gene Variation, the Growth Hormone Receptor (GHR) Exon 3 Deletion Polymorphism in a West-African Population
}

\author{
David S. Millar, Mark D. Lewis, Martin Horan, Vicky Newsway, D. Aled \\ Rees, Tammy E. Easter, Guglielmina Pepe, Olga Rickards, Martin Norin, \\ Maurice F. Scanlon, et al.
}

\section{To cite this version:}

David S. Millar, Mark D. Lewis, Martin Horan, Vicky Newsway, D. Aled Rees, et al.. Growth Hormone (GH1) Gene Variation, the Growth Hormone Receptor (GHR) Exon 3 Deletion Polymorphism in a West-African Population. Molecular and Cellular Endocrinology, 2008, 296 (1-2), pp.18. 10.1016/j.mce.2008.09.023 . hal-00532084

\section{HAL Id: hal-00532084 https://hal.science/hal-00532084}

Submitted on 4 Nov 2010

HAL is a multi-disciplinary open access archive for the deposit and dissemination of scientific research documents, whether they are published or not. The documents may come from teaching and research institutions in France or abroad, or from public or private research centers.
L'archive ouverte pluridisciplinaire HAL, est destinée au dépôt et à la diffusion de documents scientifiques de niveau recherche, publiés ou non, émanant des établissements d'enseignement et de recherche français ou étrangers, des laboratoires publics ou privés. 


\section{Accepted Manuscript}

Title: Growth Hormone (GH1) Gene Variation, the Growth Hormone Receptor (GHR) Exon 3 Deletion Polymorphism in a West-African Population

Authors: David S. Millar, Mark D. Lewis, Martin Horan, Vicky Newsway, D. Aled Rees, Tammy E. Easter,

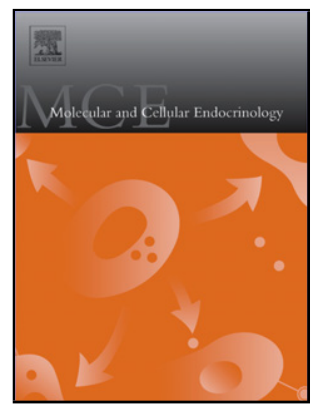
Guglielmina Pepe, Olga Rickards, Martin Norin, Maurice F. Scanlon, Michael Krawczak, David N. Cooper

PII: S0303-7207(08)00421-8

DOI: doi:10.1016/j.mce.2008.09.023

Reference: MCE 6993

To appear in: $\quad$ Molecular and Cellular Endocrinology

Received date: 29-5-2008

Revised date: 21-8-2008

Accepted date: $\quad 22-9-2008$

Please cite this article as: Millar, D.S., Lewis, M.D., Horan, M., Newsway, V., Rees, D.A., Easter, T.E., Pepe, G., Rickards, O., Norin, M., Scanlon, M.F., Krawczak, M., Cooper, D.N., Growth Hormone (GH1) Gene Variation, the Growth Hormone Receptor (GHR) Exon 3 Deletion Polymorphism in a West-African Population, Molecular and Cellular Endocrinology (2008), doi:10.1016/j.mce.2008.09.023

This is a PDF file of an unedited manuscript that has been accepted for publication. As a service to our customers we are providing this early version of the manuscript. The manuscript will undergo copyediting, typesetting, and review of the resulting proof before it is published in its final form. Please note that during the production process errors may be discovered which could affect the content, and all legal disclaimers that apply to the journal pertain. 


\section{Growth Hormone (GH1) Gene Variation and the Growth Hormone Receptor $(G H R)$ Exon 3 Deletion Polymorphism in a West-African Population}

David S. Millar ${ }^{1}$, Mark D. Lewis ${ }^{2}$, Martin Horan ${ }^{1}$, Vicky Newsway ${ }^{1}$, D. Aled Rees ${ }^{2}$, Tammy E. Easter $^{2}$, Guglielmina Pepe ${ }^{3}$, Olga Rickards ${ }^{4}$, Martin Norin ${ }^{5}$, Maurice F. Scanlon ${ }^{2}$, Michael Krawczak $^{6}$, David N. Cooper ${ }^{1}$

1. Institute of Medical Genetics, School of Medicine, Cardiff University, Heath Park, Cardiff, UK

2. Centre for Endocrine and Diabetes Sciences, Cardiff University, Heath Park, Cardiff, UK

3. Department of Medical and Surgical Critical Care, Università di Firenze, Firenze, Italy

4. Dipartimento di Biologia, Università di Roma 'Tor Vergata', Via Della Ricerca Scientifica 1, 00133, Roma, Italy

5. Biovitrum AB, Nordenflychtsvagen 62:6, SE-112 87, Stockholm, Sweden

${ }^{6 .}$ Institut für Medizinische Informatik und Statistik, Christian-Albrechts-Universität, Arnold-Heller-Straße 3, 24105 Kiel, Germany

Address for all correspondence: Dr. David S. Millar, Institute of Medical Genetics, School of Medicine, Cardiff University, Heath Park, Cardiff CF14 4XN, UK. Tel: +442920744034 Fax: +44 2920747603 Email: millar@ cardiff.ac.uk 


\begin{abstract}
Among Europeans, functionally significant $G H 1$ gene variants occur not only in individuals with idiopathic growth hormone $(\mathrm{GH})$ deficiency and/or short stature but also fairly frequently in the general population. To assess the generality of these findings, 163 individuals from Benin, West Africa were screened for mutations and polymorphisms in their $\mathrm{GH} 1$ genes. A total of 37 different sequence variants were identified in the $G H 1$ gene region, 24 of which occurred with a frequency of $>1 \%$. Although four of these variants were novel missense substitutions (Ala13Val, Arg19His, Phe25Tyr and Ser95Arg), none of these had any measurable effect on either GH function or secretion in vitro. Some 37 different GH1 promoter haplotypes were identified, 23 of which are as yet unreported in Europeans. The mean in vitro expression level of the $\mathrm{GH} 1$ promoter haplotypes observed in the African population was significantly higher than that previously measured in Britons $(\mathrm{p}<0.001)$. A gene conversion in the $\mathrm{GH} 1$ promoter, previously reported in a single individual of British origin, was found to occur at polymorphic frequency $(5 \%)$ in the West-African population and was associated with a 1.7-fold increase in promoter activity relative to the wild-type. The $\mathrm{d} 3$ allele of the GHR exon 3 deletion polymorphism, known to be associated with increased $\mathrm{GH}$ responsiveness, was also found to occur at an elevated frequency in these individuals from Benin. We speculate that both elevated $G H 1$ gene expression and increased GHR-mediated GH responsiveness may constitute adaptive responses to the effects of scarce food supply in this West-African population since increased circulating $\mathrm{GH}$ appears to form part of a physiological response to nutritional deprivation.
\end{abstract}

Keywords: Growth hormone; Growth hormone receptor; Benin; Missense mutations; Promoter haplotype; Gene conversion; Gene expression 


\section{Introduction}

Human growth hormone $(\mathrm{GH})$ is a pleiotropic cytokine that promotes the postnatal growth of skeletal and soft tissue as well as acting as an important regulator of bone turnover, muscle mass and immune function. The biological action of GH is mediated through the activation of its cell surface receptor, GHR. Each GH molecule has two binding sites, ensuring that the binding of GH to GHR results in the formation of a receptor homodimer. Interaction of dimerized GHR with the intracellular tyrosine kinase JAK-2 leads to the phosphorylation of downstream signal transduction molecules, induction of signal transducers and activators of transcription (STAT) proteins, and stimulation of mitogen-activated protein (MAP) kinases (Waters et al., 2006). Activated STAT5 is then translocated to the nucleus where it transactivates a series of GH-responsive genes.

In humans, GH synthesis is directed by the pituitary-expressed $\mathrm{GH} I$ gene which is located on chromosome 17q23 within a cluster of five highly homologous and placentally expressed genes: two chorionic somatomammotropin genes ( $\mathrm{CSH} 1$ and $\mathrm{CSH} 2$ ), a second GH-related gene $(\mathrm{GH} 2)$ and a chorionic somatomammotropin pseudogene (CSHP1). GH1 gene expression is controlled both by the proximal promoter and a locus control region (LCR) located between $14.5 \mathrm{~kb}$ and $32 \mathrm{~kb}$ upstream of the $G H 1$ gene (Jones et al., 1995). The LCR contains multiple DNase I hypersensitive sites and is required for the activation of the genes of the GH cluster in both pituitary and placenta (Su et al., 2000; Ho et al., 2002). Two DNase I hypersensitive sites (I and II) contain binding sites for the pituitary-specific transcription factor Pit-1 and are responsible for the high level-, somatotroph-specific expression of the $\mathrm{GHI}$ gene (Shewchuk et al., 1999, 2002). It has been shown that polymorphic variation in the proximal promoter region of the $\mathrm{GH} l$ gene influences GH1 gene expression and may thus contribute to the heritability of human stature (Hasegawa et al., 2000; Horan et al., 2003; Giordano et al., 2006; Giordano et al., 2008). The proximal promoter region of the GHI gene contains at least 15 single nucleotide polymorphisms (SNPs) (Giordano et al., 1997; Wagner et al., 1997). In the European population, this variation has been found to manifest itself in at least 40 different haplotypes, the high diversity being explicable in terms of gene conversion, recurrent mutation and selection (Giordano et al., 1997; Horan et al., 2003; Chen et al., 2007; Wolf et al., 2008). Functional analysis demonstrated that haplotypes associated with a markedly reduced level of reporter gene expression were more prevalent in the European population than those haplotypes associated with an increased level, possibly as a consequence of selection (Horan et al., 2003). It has also been demonstrated that $\mathrm{GHI}$ gene variants occur not only in individuals with idiopathic GH deficiency and/or short stature but also fairly frequently in the general (European) population (Millar et al., 2003; Esteban et al., 2007).

The human growth hormone receptor $(G H R)$ gene on chromosome 5p13-p12 is also polymorphic, with polymorphisms described in exons 3, 6 and 10 (Buzi et al., 2007). The exon 3 polymorphism gives rise to exon 3-containing (fl) and exon 3-deleted (d3) isoforms (Pantel et al., 2000). In the Western European population, the $\mathrm{d} 3$ (deletion) allele occurs at a frequency of $\sim 50 \%$ (Dos Santos et al., 2004; Binder et al., 2006; Pilotta et al., 2006; Carrascosa et al., 2006; Blum et al., 2006) and has been reported to be associated with an increased growth response to exogenous human GH (Dos Santos et al., 2004). This has, however, become a contentious issue since although some studies have concurred with the initial findings (Jorge et al., 2006; Binder et al., 2006; Jensen et al., 2007; Tauber et al., 2007; Binder et al., 2008; Räz et al., 2008), 
various other studies (Pilotta et al., 2006; Carrascosa et al., 2006; Blum et al., 2006; Kenth et al., 2007; Carrascosa et al., 2008) have failed to replicate the original association (Buzi et al., 2007).

In an attempt to test the generality of the above mentioned observations in a nonEuropean population, a group of healthy individuals from Benin, West Africa was screened for mutations and polymorphisms in their $G H 1$ genes and genotyped for the $G H R$ exon $\mathrm{fl} / \mathrm{d} 3$ deletion polymorphism.

\section{Materials and Methods}

\subsection{DNA samples}

DNA samples were obtained from 163 individuals from Benin, West Africa, as previously described (Pepe et al., 1999). These individuals came from four different tribes: Bariba (41 individuals; 30 males, 11 females), Berba (33 individuals; 13 males, 20 females), Fon (44 individuals; 29 males, 15 females) and Dendi (45 individuals; 34 males, 11 females). No height data were available from these individuals. DNA samples from 156 male British army recruits (Horan et al., 2003; Millar et al., 2003) were also included in the analysis of the $G H R \mathrm{~d} 3$ polymorphism.

\subsection{Detection of sequence variants within the GHI gene}

A $3.2 \mathrm{~kb}$ fragment specific to the $G H 1$ gene was PCR-amplified for all individuals (Millar et al., 2003) using oligonucleotide primers GH1F (5'

GGGAGCCCCAGCAATGC 3'; -615 to -599) and GH1R (5'

TGTAGGAAGTCTGGGGTGC 3'; 2598 to 2616) [numbering relative to the transcriptional initiation site at +1 (GenBank accession number J03071)]. These PCR fragments were then directly sequenced to identify sequence variants within the entire coding region, introns, 5' and 3'untranslated regions and promoter of the $G H 1$ gene. The oligonucleotide primers used for sequencing were GH1BF (5', GTGGTCAGTGTTGGAACTGC 3'; -556 to -537), GH1SEQ1 (5' CCACTCAGGGTCCTGTG 3'; +27 to +43), GH1SEQ2 (5' GGAGGAGACTAAGGAGCTC 3'; +556 to +584) and GH1SEQ3 (5' TTAGAGAAACACTGCTGCCC 3 '; +1137 to +1156 ) as previously described (Millar et al., 2003). In cases where individuals were heterozygous at two or more positions throughout the gene, the $3.2 \mathrm{~kb} \mathrm{GHl}$ gene fragments were cloned into the cloning vector pGEM-T (Promega, UK) and four clones were sequenced to identify unambiguously the respective haplotypes.

\subsection{Haplotype analysis of the exon 3 GHR polymorphism}

Haplotype analysis of the exon $3 G H R$ polymorphism was carried out in 156 Britons and 154 Beninese using quantitative (Q-PCR) PCR as previously described (Horan et al., 2006). Briefly, primer/probe sets targeted to exons 3 and 10 of the human $G H R$ gene. GHR exon 10 served as an internal positive control. Oligonucleotide primers and probe used for exon 3 of the GHR gene were: GHRX3F (5' TCTGTTTCAGCCACAGCAGCTA 3'; +159 to +180) and GHRX3R (5' TGTCTTTAGGCCTGGATTAACACTT 3'; +233 to 209) with the FAM-labelled probe GHRX3 (5' FAM-CCTTAGCAGAGCACCCTGGAGTCTGC-TAMRA 3'; +182 to +207 ). Oligonucleotide primers and probe used for exon 10 were: GHRX10F 
(5' CCCAGGTGAGCGACATTACA 3'; +2471 to +2490) and GHRX10R (5' CATCCCTGCC TTATTCTTTTGG 3'; +2541 to +2519) with the VIC-labelled probe GHRX10 (5' VIC-CAGCAGGTAGTGTGGTCC TTTCCCCG-TAMRA 3'; +2492 to +2517). Primer and probe positions are based on GenBank accession number AH002706. Q-PCR s performed in 96 well plates with 50ng genomic DNA in a volume of 12.5 $\mu 1$ using 2x Taqman Universal PCR Master Mix (Applied Biosystems), $1.25 \mu \mathrm{l} \mathrm{GHR}$ exon 3 primers/probe ( $3 \mathrm{pm} / \mu \mathrm{l}$ each), $1.25 \mu \mathrm{l} G H R$ exon 10 primers/probe $\left(9 \mathrm{pm} / \mu \mathrm{l}\right.$ each) and $2.75 \mu \mathrm{l}$ sterile water. Cycle conditions were $50^{\circ} \mathrm{C} 2 \mathrm{~min}, 95^{\circ} \mathrm{C} 10$ min followed by 40 cycles of $95^{\circ} \mathrm{C} 15 \mathrm{sec}$, and $60^{\circ} \mathrm{C} 1 \mathrm{~min}$.

\subsection{Analysis of promoter haplotypes by luciferase reporter gene assay}

Individual examples of the 26 different $G H 1$ proximal promoter haplotypes that were both novel and specific to the Beninese population (Table 2) were PCRamplified using oligonucleotide primers GHPROM5

(5' AGATCTGACCCAGGAGTCCTCAGC 3'; -520 to -501) and either GHPROM3A (5' AAGCTTGCAGCTAGGTGAGCTGTC 3'; + 44 to +62) or GHPROM3C (5' AAGCTTGCCGCTAGGTGAGCTGTC 3'; + 44 to +62) depending upon the base at position +59 of the haplotype. To facilitate cloning, partial or complete restriction endonuclease recognition sites were added to the 5' end of the primers (underlined above): BgIII (GHPROM5) and HindIII (GHPROM3A and GHPROM3C). Following restriction endonuclease digestion, fragments were cloned into the luciferase reporter gene expression vector pGL3Basic (Promega, UK) as described by Horan et al. (2003).

Luciferase reporter gene assays were then performed in rat GC pituitary cells in sextuplicate on three separate occasions as described (Horan et al., 2003). Briefly, GC cells were plated out into 96 -well plates so as to be $\sim 80 \%$ confluent the following day in DMEM containing $15 \%$ horse serum and $2.5 \%$ fetal calf serum (FCS). The transfection mixture contained 250ng pGL3 haplotype construct, 1ng pRL-CMV (Promega) and $0.5 \mu 1 \mathrm{Tf}^{\mathrm{TM}}-20$ (Promega) in a total volume of $90 \mu \mathrm{l}$ serum-free medium per well. After $1 \mathrm{hr}, 200 \mu \mathrm{l}$ complete medium was added to each well and incubated for $24 \mathrm{hr}$ at $37^{\circ} \mathrm{C}$ in $5 \% \mathrm{CO}_{2}$ before being lysed for the reporter assay. Luciferase assays were performed using the Dual Luciferase Reporter Assay System (Promega). Assays were performed on a microplate luminometer (Applied Biosystems) and then normalised with respect to Renilla activity.

\subsection{Site-directed mutagenesis}

Site-directed mutagenesis (SDM) was performed as previously described (Millar et al., 2003) on the luciferase reporter gene construct, pGL3H43, containing the GH1 gene promoter haplotype 43. SDM was used to change the region -53 to -39 of the $\mathrm{GH} 1$ gene promoter sequence to that of the paralogous $\mathrm{CSH} 1$ gene promoter sequence (a change which corresponds to the common gene conversion polymorphism noted in the West-African population). This construct (pGL3H43GC) and pGL3H43 were then used in a second SDM reaction to introduce the associated A+10G sequence variant (which was invariably found in cis to the gene conversion) into both constructs to yield pGL3H43GC+10G and pGL3H43+10G respectively. Following SDM, all mutated $\mathrm{GH} 1$ promoter/luciferase reporter gene constructs were sequenced in order to ensure that only the desired changes had been introduced.

\subsection{In vitro expression of missense $G H$ variants}


Wild-type GH1 cDNA (transcript variant 1; Accession number NM_000515) was cloned into the insect expression vector pIZ/V5-His (Invitrogen) and modified by SDM to generate cDNA constructs containing the novel missense GH variants detected in the present study (Millar et al., 2003). These vectors were then transfected into High Five insect cells (Invitrogen) as described by Millar et al. (2003). Human $\mathrm{GH}$ was quantified in the culture supernatants by ELISA (DRG Instruments GmbH, Marburg, Germany). The cross-reactivity in the ELISA of the GH variant and insect cell-expressed wild-type GH was confirmed by dilution analysis to be equal to that of the assay reference preparation (calibrated against the MRC 1st IRP 80/505 reference preparation).

\subsection{Luciferase reporter gene assay of STAT 5 activation}

HK293 cells, previously transfected with the full-length human GHR gene and selected on the basis of elevated GHR expression (HK293hi) (Ross et al., 1997), were used to assay the STAT 5 activation potential of each GH-coding sequence variant. HK293hi cells were transfected with a STAT 5-responsive luciferase reporter gene construct and treated with GH (wild-type and variant) for 6 hours. Luciferase expression was measured as previously described (Lewis et al., 2004).

\subsection{GH secretion assays}

The rat pituitary (GC) cell line was transfected with a pGEM-T plasmid containing a $3.2 \mathrm{~kb}$ fragment spanning the entire wild-type $\mathrm{GH} 1$ gene (under the control of promoter haplotype 1) and equivalent constructs for the missense variants also under the control of haplotype 1. Cells (200,000 cells per well) were plated onto 24-well plates and cultured in complete medium (DMEM, 15\% Horse serum, 2.5\% FCS). Cells were transfected with 500ng GH1 plasmid and $\beta$-galactosidase expression vector (pCH110; GE Healthcare) using $1 \mu 1 \mathrm{Tf}^{\mathrm{TM}}-20$ in $200 \mu \mathrm{l}$ serum-free medium for $1 \mathrm{hr}$ after which $0.5 \mathrm{ml}$ complete medium was added to each well. Cells were cultured for $48 \mathrm{hr}$, medium harvested, and cells lysed for $\beta$-galactosidase assay to correct for differences in transfection efficiency. GH in the medium was measured for all variants using a human GH IRMA (Nichols Institute Diagnostics) that showed no croos-reactivity to rat $\mathrm{GH}$.

\subsection{Molecular modelling}

Missense variants were modelled as previously described (Millar et al., 2003).

\subsection{Determination of evolutionary conservation of specific $G H$ amino acid residues}

The evolutionary conservation of the amino acid residues harbouring missense changes was examined by ClustalW multiple sequence alignment [http://www.ebi.ac.uk/Tools/clustalw] of orthologous GH proteins from 19 vertebrate species, including mammals, birds, reptiles, amphibians and fish (see Supplementary Table 1 and Supplementary Figure 1).

\subsection{Statistical analysis}

Luciferase measurements of $G H 1$ promoter-driven transcription were normalised as follows: First, $\mathrm{GH} 1$ promoter activity values were divided by the corresponding Renilla activity value of the same construct. Next, the mean ratio of the negative controls on a given plate was subtracted from all other ratios on the same plate. The mean (plate-corrected) activity ratio for proximal promoter haplotype 1 (H1) on each plate was then calculated, and all other haplotype-specific activity ratios on the same plate divided by this value. These two transformations ensured that the mean 
normalised activity of the negative controls equalled zero whilst the mean normalised activity of $\mathrm{H} 1$ equalled unity, independent of plate number. Normalised activities may thus be interpreted as -fold changes by comparison with $\mathrm{H} 1$, corrected for transcription efficiency, baseline and plate effects. Since no significant plate effects were detectable after transformation, the data were combined over all plates. The population difference in terms of the mean expression level of haplotypes was assessed for statistical significance using a Student t-test. The relationship between the mean expression levels and the population frequencies of haplotypes was analysed using Spearman rank correlation coefficients, with significance assessment carried out using a $\mathrm{z}$-approximation. Allele frequency differences between populations were tested for statistical significance using a Pearson $\chi^{2}$ test. Differences between genotype-specific and wild-type bioactivity measurements $\left(\mathrm{EC}_{50}\right.$ and percentage $\mathrm{GH}$ secretion) were assessed for statistical significance using ANOVA.

\section{Results}

A total of 37 different sequence variants (excluding the 15 promoter SNPs used to define the promoter haplotypes) were identified in the $G H 1$ genes of 163 Beninese individuals. Of these variants, 13 occurred in the $G H 1$ gene promoter/5' UTR, 15 within intronic sequence and 9 in the coding sequence. Twenty-four $(65 \%)$ of the detected variants occurred at a frequency of $>1 \%$ in our study ( 7 promoter, 11 intronic, 6 coding sequence) and may therefore be formally regarded as being polymorphisms in the Beninese population. Table 1 lists the frequency and location of these polymorphic $\mathrm{GH} 1$ variants together with the predominant associated promoter haplotype (if any). Among these variants were three novel coding sequence changes (Ala13Val, Phe25Tyr and Ser95Arg) and a gene conversion spanning a minimum of $16 \mathrm{bp}$ of the $\mathrm{GH} 1$ promoter/5'UTR. In addition, solitary examples of Arg19His and Ile179Met substitutions were detected in association with promoter haplotypes $\mathrm{H} 43$ and $\mathrm{H} 45$, respectively.

In addition, a total of 37 different $G H 1$ promoter haplotypes were identified in the 163 Beninese individuals studied (Table 2). The observed GH1 promoter haplotype frequencies in the Beninese samples were compared to those reported from 303 white Europeans (156 British, 116 Spanish, 31 French), previously genotyped by Horan et al. (2003) and Lewis et al. (2004). Of the Beninese promoter haplotypes, 23 were novel whereas 14 had been previously identified in individuals of European origin. The most common promoter haplotype in Africans (H1) was found to be identical to that predominating in Europeans. Although the two next most common promoter haplotypes in the Beninese population ( $\mathrm{H} 8$ and $\mathrm{H} 23$ ) were also found in Europeans, their frequency in the Beninese was considerably higher. When assessed in a luciferase reporter gene assay (Table 2), the relative promoter strength of the novel Beninese promoter haplotypes was found to vary only two-fold (82\% to $170 \%$ that of $\mathrm{H} 1)$, a somewhat lower range than that previously observed among Europeans (33\% to $189 \%$; Horan et al., 2003; Table 2). Accordingly, the mean normalised expression level (relative to H1) was significantly higher among African alleles (98.6\%, SD: 29.3\%) than among European alleles (83.9\%, SD: 23.6\%, Student t: 8.243, 930 d.f., $\mathrm{p}<0.001$ ). On the other hand, whilst the population frequencies of the GH1 haplotypes were inversely correlated with their respective in vitro expression levels (as measured by the mean luciferase activity, and given in Table 2) in the European group (Spearman rank correlation coefficient $r=-0.361, p=0.02$ ), this was not the case for the Beninese group $(r=-0.189, p=0.26)$. 
Of the nine coding sequence variants detected in this study, six were associated with missense changes, of which four were novel (Ala13Val, Arg19His, Phe25Tyr and Ser95Arg). Two variants (Thr3Ala and Ile179Met) have been previously described (Miyata et al., 1997; Lewis et al., 2004).

The Thr3Ala variant previously noted in both Europeans (Millar et al., 2003) and Japanese (Miyata et al., 1997) is considered to be a neutral polymorphism lacking any functional effect (Millar et al., 2003). The presence of the Ala3 variant on a variety of different $G H 1$ promoter haplotypes in three different racial groups is compatible with the occurrence of multiple independent gene conversion events during and after the expansion of modern humans out of Africa. Such gene conversion events could have been mediated by the $C S H P 1, G H 2$ or $C S H 2$ gene.

The Ile179Met missense mutation, previously reported in a Spanish child of short stature, has been found to result in the loss of the ability of GH to activate the extracellular signal-regulated kinase pathway despite having normal ability to activate STAT5 (Lewis et al., 2004). In the Spanish patient, the nucleotide substitution underlying Ile179Met $(\mathrm{C}+1491 \mathrm{G})$ was present on an H1 haplotype background and was in cis to $+1169 \mathrm{~T}$. By contrast, the solitary example of the occurrence of this mutation in a Beninese individual was associated with haplotype $\mathrm{H} 45$ and was in cis to $+1169 \mathrm{~T}$ and two other sequence variants, A-360G and T-352G. Since A-360G and T-352G were not associated with the Ile179Met mutation in the Spanish patient, it is unlikely that the two Ile179Met mutations are identical by descent. In this context, it is pertinent to note that the Ile179Met substitution could also have been mediated by gene conversion, templated either by the $\mathrm{CSH} 1, \mathrm{CSH} 2$ or $\mathrm{CSHP} 1$ gene.

Four novel GH1 missense mutations (Ala13Val, Arg19His, Phe25Tyr and Ser95Arg) were also identified in the Beninese samples. However, only Phe25Tyr could have been templated by gene conversion, the potential donor sequence being the $\mathrm{GH} 2$ gene. None of these missense variants appears to have any detrimental effect on GH function, as measured by a STAT5-luciferase reporter gene assay (Table 3), or affect the secretion of the protein as compared to the wild-type (Table 3). Details of the evolutionary conservation of the residues harbouring these missense variants and their predicted interactions with the GHR can be found in the Supplementary Results section.

One of the more common $G H 1$ variants in the Benin population (with a frequency of 5\%) involves the concomitant introduction of five nucleotide sequence changes (see Fig. 1) into the promoter/5'UTR. These changes appear to have arisen as a consequence of gene conversion templated either by the $\mathrm{CSH} 1$ or $\mathrm{CSH} 2$ gene. The minimum extent of the conversion event was -53 to -39 whilst the maximum was -112 to $+9(\mathrm{CSH} 1)$ or -123 to $+9(\mathrm{CSH} 2)$, depending upon the identity of the donor sequence (Fig. 1). Three of the five nucleotide changes were located within the vitamin D receptor binding site (Fig. 1), a negative regulatory element in the human GH1 gene (Seoane et al., 2002). In terms of the component nucleotide sequence changes, it is therefore identical to the gene conversion event previously reported in a healthy European of above average height (individual S121; Millar et al., 2003).

Whereas the solitary example of the European gene conversion occurred on promoter haplotype $\mathrm{H} 22$, its Beninese counterpart occurred at polymorphic frequency and invariably on promoter haplotype H43. Since H22 differs from H43 at four distinct positions within the promoter region viz. $-308,-301,-6$ and -1 (these bases being T, T, A and A respectively in $\mathrm{H} 22$ and $\mathrm{G}, \mathrm{G}, \mathrm{G}$ and $\mathrm{T}$ in $\mathrm{H} 43$ ), it follows that the two haplotypes cannot be readily inter-converted by sequential single base-pair substitutions. In addition, whilst the gene conversion in the Benin population was 
found in cis with A+10G in all cases and with C+438T (Ala13Val) in 17/18 cases, the European gene conversion was associated with G-373A. Both gene conversions were found to be in cis to a $\mathrm{T}$ at +1169 , the frequency of which was $0.37(115 / 312)$ in Europeans as compared to 0.03 (10/326) in the Beninese population. We therefore surmise that the gene conversion event in question must have occurred independently on at least two separate occasions in the European and Beninese populations.

In order to determine whether the linked A+10G substitution contributes to the high expression of the gene conversion allele, the two variants were studied both individually and in combination. Luciferase reporter gene assays were performed in sextuplicate on three separate occasions; data were normalised as described above and the haplotype-associated activities of pGL3H43GC, pGL3H43+10G and pGL3H43GC+10G were divided by those of pGL3H43. This ensured that (i) the mean activity of $\mathrm{H} 43$ equalled unity in each comparison and (ii) the derived activity values for $\mathrm{H} 43 \mathrm{GC}, \mathrm{H} 43+10 \mathrm{G}$ and $\mathrm{H} 43 \mathrm{GC}+10 \mathrm{G}$ could be given as -fold changes relative to their respective background promoter haplotypes (Table 4). Irrespective of the background promoter haplotype, it would appear that the gene conversion event gives rise to an increase in promoter activity. By contrast, the A+10G substitution serves to reduce promoter activity when associated with haplotype H43, thereby partially counteracting the effect of the gene conversion.

Analysis of the exon $3 \mathrm{GHR}$ deletion polymorphism was performed on 156 British and 154 Beninese DNA samples as described by Horan et al. (2006) (Figure 2). The frequency of the $G H R \mathrm{~d} 3$ allele was found to be significantly higher in the Benin population than in the British sample $\left(47 \%\right.$ vs. $28 \%, \chi^{2}=22.64,1$ d.f., $\left.p<0.0001\right)$ and consequently $70 \%$ of the Beninese population possess either a $\mathrm{d} 3 / \mathrm{d} 3$ or $\mathrm{fl} / \mathrm{d} 3$ genotype as compared to $47 \%$ of Britons. The observed GHR d3 genotype frequencies in the British population were in broad agreement with those previously reported from other European populations (Dos Santos et al., 2004; Binder et al., 2006; Pilotta et al., 2006; Carrascosa et al., 2006; Blum et al., 2006). Genotype frequencies did not deviate significantly from Hardy-Weinberg equilibrium in either the British or Beninese groups. No significant association was apparent between GHR genotype and GH1 promoter haplotype or any of the missense variants detected in this study.

\section{Discussion}

Growth hormone (GH), encoded by the $G H 1$ gene, plays an important role in human development, growth and metabolism (Kaplan 1999). The biological effects of GH are mediated by binding to a GHR dimer present on the cell surface, thereby initiating a signalling cascade which results in an increased plasma level of IGF-1. We and others have previously documented an unparalleled level of $G H 1$ gene variation in people within the range of normal stature (Giordano et al., 1997; Wagner et al., 1997; Hasegawa et al., 2000; Horan et al., 2003; Millar et al., 2003; Giordano et al., 2006; Giordano et al., 2008). We have also expressed the view that selection for variation in stature alone is insufficient to explain this degree of genetic variability and that selection for multiple GH-related phenotypic traits has probably been responsible for creating it (Millar et al., 2003). In an attempt to relate the extensive genetic variation found in the $\mathrm{GH} 1$ gene to GH structure, function and expression, a group of individuals from Benin in West Africa was screened both for mutations and polymorphisms in their $G H 1$ genes.

The results of this analysis have indicated that the human $G H 1$ gene is at least as polymorphic in the West-African population as in the European population. This is exemplified by the haplotype diversity observed for the 15 SNPs located in the GHI 
promoter, which was $88.2 \%$ in the Beninese population as compared to $87.6 \%$ in the Europeans. This is consistent with the recently published findings of Sedman et al. (2008) who also studied GH1 gene diversity in individuals (Mandenka) from West Africa.

Four novel coding sequence variants (Ala13Val, Arg19His, Phe25Tyr and Ser95Arg) were identified here, three of which (Ala13Val, Phe25Tyr and Ser95Arg) were found to occur at a frequency of $>1 \%$. Functional analysis of these variants revealed that they were indistinguishable from wild-type $\mathrm{GH}$ in terms of (i) their ability to activate the JAK-STAT signalling pathway and (ii) their secretion from GC cells.

The most frequent promoter haplotype in the Beninese population was found to be $\mathrm{H} 1$ (26\%) which is also known to be the predominant haplotype in Britons (33\%; Horan et al., 2003). This finding is consistent with an ancient origin for $\mathrm{H} 1$ that must have preceded the divergence of the two ethnic groups over the last $\sim 150,000$ years (Wolf et al., 2008). Of the 37 promoter haplotypes found in the Beninese population, 23 were found to be unique (Table 2) to this population whereas 14 (including H1) have also been noted in Britons.

Assessment of the correlation between haplotype frequency and expression level previously revealed that those promoter haplotypes associated with a reduced level of reporter gene expression tend to be more prevalent in the British population (Horan et al., 2003), possibly as a consequence of selection. This was not however found to be the case in the Beninese population. Indeed, the average expression level of the GHI promoter haplotypes was significantly higher in the Beninese than in the European population sample. This discrepancy may be explicable in terms of differential selection operating in the two populations with respect to the phenotypic consequences of reduced $G H 1$ gene expression. In view of the relatively low proportion of variance in adult body height explicable by $G H 1$ gene expression variability (Horan et al. 2003), differential selection appears very unlikely to have been mediated by stature alone but could instead reflect other factors e.g. fetal development, nutritional balance between mother and child, resistance to starvation, infection or trauma (Millar et al., 2003).

The gene conversion polymorphism detected in the present study constituted $\sim 5.5 \%$ of Beninese $\mathrm{GH} 1$ alleles. Although polymorphic gene conversions in human genes are generally rare, they are not wholly unprecedented (e.g. Ohta 1999; Matsubara et al., 2001; Ogasawara et al., 2001). Indirect evidence has been previously presented for their probable occurrence in the human GHI gene (Giordano et al., 1997). The gene conversion reported here resulted in the partial replacement of the wild-type $G H 1$ promoter sequence, specifically introducing five nucleotide substitutions [including three within the negative vitamin D response element (VDRE); Seoane et al., 2002]. The European version of this mutation, present on haplotype H22, was previously found to drive reporter gene expression to $182 \pm 6 \%$ that of the wild-type $\mathrm{H} 22$ construct (Millar et al., 2003). Since we have shown that reporter gene expression is also elevated to $174 \pm 4 \%$ in the context of haplotype H43 (Table 4), it appears likely that the gene conversion-derived alleles increase the expression of the $G H 1$ gene in a haplotype-independent fashion, perhaps by perturbing the putative negative VDRE regulatory element. In the West-African group, the gene conversion was associated exclusively with haplotype H43, consistent with the view that all extant copies of the allele are identical by descent in this population. $\mathrm{H} 43$ is the second highest of the novel African promoter haplotypes in terms of its in vitro expression level - it is however unclear whether this is simply coincidental or whether this high level of 
expression has perhaps contributed to the spread of the haplotype through the population. This question notwithstanding, it is clear that the gene conversion event has recurred independently in European and African populations.

The gene conversion was found to occur in cis to a 5 ' UTR substitution $(A+10 G)$ in all cases and the Ala13Val $(\mathrm{C}+438 \mathrm{~T})$ substitution in all but one case. Neither of these nucleotide substitutions could have been mediated by gene conversion since the various paralogous genes at the $\mathrm{GH}$ locus all contain an adenine $(\mathrm{A}+10 \mathrm{G})$ or cytosine $(\mathrm{C}+438 \mathrm{~T})$ at the analogous locations. This suggests that the three lesions did not occur contemporaneously as part of the same mutational event but rather that $\mathrm{A}+10 \mathrm{G}$ and $\mathrm{C}+438 \mathrm{~T}$ probably occurred on a chromosome already bearing the gene conversion. This assertion is, however, based on the sequence alignment of the paralogous GH genes from a European, not a West-African, population; the nucleotides at these positions may well be different in Africans and Europeans (although it should be pointed out that this was not found by Sedman et al., 2008). Although the Ala13Val variant has no effect on GH function or secretion, the H43 haplotype bearing the $+10 \mathrm{G}$ variant is associated with a reduction in $\mathrm{GH} 1$ promoter activity to $\sim 80 \%$ of that of the $+10 \mathrm{~A}$-bearing H43 haplotype. The presence of the $+10 \mathrm{G}$ variant in cis to the gene conversion serves to reduce promoter activity from 1.74- to 1.33-fold of the +10 A-bearing H43. Since H43 has the second highest in vitro expression level of all haplotypes (1.35-fold higher than $\mathrm{H} 1$ ), the presence of the $+10 \mathrm{G}$ allele simply reduces the level of promoter activity associated with $\mathrm{H} 43$ to that seen with $\mathrm{H} 1$.

Analysis of the GHR exon 3 deletional (d3) polymorphism in the Beninese population indicated that the frequency of the $\mathrm{d} 3$ allele was rather higher than in the British population ( $48 \%$ vs. $28 \%$ ). The $\mathrm{d} 3$ allele has been shown to be associated with increased GH responsiveness (Dos Santos et al., 2004) and was found to be positively correlated with postnatal growth velocity and near-final height in a group of 115 healthy adolescents (Jensen et al., 2007). Atzmon et al. (2006) found that heterozygotes for the $G H R \mathrm{~d} 3$ allele exhibited reduced insulin sensitivity as compared to $G H R \mathrm{fl}$ homozygotes, suggesting that the $G H R \mathrm{~d} 3$ allele may also play a role in metabolism as well as in growth velocity.

Our results suggest that both high expressing $\mathrm{GH} 1$ promoter haplotypes and the $G H R \mathrm{~d} 3$ allele could have been selected for in the West-African population, possibly in response to persistent under-nutrition (Luke et al., 2001). Starvation is known to result in an increase in circulating GH level secondary to an increase in GH pulse frequency and amplitude (Hartman et al., 1992). Coupled with reduced insulin secretion, this leads to increased lipolysis and ketogenesis, insulin resistance and conservation of glucose and protein (Nørrelund 2005). The maintenance of a high level of circulating GH in malnourished individuals may therefore have been of selective value. However, increased lipolysis gives rise to elevated levels of circulating free fatty acids which have been shown, at least in vitro, to decrease expression of GHR by 50\% (Thimmarayappa et al., 2006). Decreased amounts of GHR on the cell surface would be expected to lead to reduced secretion of IGF1. The presence of at least one GHR $\mathrm{d} 3$ allele in $70 \%$ of the West African population may serve to ameliorate the effects of decreased expression of the GHR by virtue of its increased responsiveness to $\mathrm{GH}$ ( $\sim 30 \%$ greater than for GHR $\mathrm{fl}$ homozygotes; Dos Santos et al., 2004) and IGF1 levels may consequently be near normal.

The data from our in vitro GHI promoter expression study suggest that the WestAfrican population may well be characterized by an increased level of circulating GH. This is compatible with the in vivo data of Wright et al. (1995) who found that the circulating GH level was significantly higher in African-Americans than in their 
European-American counterparts. Were the frequency of the GHR $\mathrm{d} 3$ allele in African-Americans to be comparable to that seen in the West-African population, then those African-Americans possessing the $G H R \mathrm{~d} 3$ allele may be more responsive to $\mathrm{GH}$, leading to increased circulating levels of IGF1. However, in studies of adults and post-pubertal adolescents, no significant differences in IGF1 levels were noted between African-Americans and European-Americans (Wright et al., 1995; Arslanian and Suprasongsin, 1996; Arslanian 1998) although IGF1 levels were found to be significantly higher in the African-American group in pre-pubertal children (Arslanian 1998). All such comparisons between African-Americans and European-Americans should however be viewed with caution both because of genetic admixture (Parra et al., 1998) and because of the lifestyle differences between the two populations. Further study of GH and IGF1 levels is therefore necessary in the indigenous WestAfrican population in order to account for the initial intriguing findings in AfricanAmericans.

\section{References}

Alonso, M., Segura, C., Dieguez, C., Perez-Fernandez, R., 1998. High-affinity binding sites to the vitamin D receptor DNA binding domain in the human growth hormone promoter. Biochem. Biophys. Res. Commun. 247, 882-887.

Arslanian, S., 1998. Insulin secretion and sensitivity in healthy African-American vs American white children. Clin. Pediatr. 37, 81-88.

Arslanian, S., Suprasongsin, C., 1996. Differences in the in vivo insulin secretion and sensitivity of healthy black versus white adolescents. J. Pediatr. 129, 440-443.

Atzmon, G., Muzumdar, R., Budagov, T., Barzilai, N., Cohen, P., 2006. The growth hormone receptor exon-3 deletion is a marker for exceptional longevity. Growth Hormone IGF Res. 16, S9-S10.

Binder, G., Baur, F., Schweizer, R., Ranke, MB., 2006. The d3-growth hormone (GH) receptor polymorphism is associated with increased responsiveness to $\mathrm{GH}$ in Turner syndrome and short small-for-gestational-age children. J. Clin. Endocrinol. Metab. 91, 659-664.

Binder, G., Trebar, B., Baur, F., Schweizer, R., Ranke, MB., 2008. Homozygosity of the $\mathrm{d} 3$-growth hormone receptor polymorphism is associated with a high total effect of GH on growth and a low BMI in girls with Turner syndrome. Clin. Endocrinol. (Oxf). 68, 567-572.

Blum, W.F., Machinis, K., Shavrikova, E.P., Keller, A., Stobbe, H., Pfaeffle, R.W., Amselem, S., 2006. The growth response to growth hormone (GH) treatment in children with isolated GH deficiency is independent of the presence of the exon 3minus isoform of the GH receptor. J. Clin. Endocrinol. Metab. 91, 4171-4174.

Buzi, F., Mella, P., Pilotta, A., Prandi, E., Lanfranchi, F., Carapella, T., 2007. Growth hormone receptor polymorphisms. Endocr. Dev. 11, 28-35. 
Carrascosa, A., Esteban, C., Espadero, R., Fernández-Cancio, M., Andaluz, P., Clemente, M., Audí, L., Wollmann, H., Fryklund, L., Parodi, L.; Spanish SGA Study Group., 2006. The d3/fl-growth hormone (GH) receptor polymorphism does not influence the effect of GH treatment (66 microg/kg per day) or the spontaneous growth in short non-GH-deficient small-for-gestational-age children: results from a two-year controlled prospective study in 170 Spanish patients. J. Clin. Endocrinol. Metab. 91, 3281-3286.

Chen, J.-M., Cooper, D.N., Chuzhanova, N., Férec, C., Patrinos, G.P., 2007. Gene conversion: mechanisms, evolution and human disease. Nat. Rev. Genet. 8, 762-775.

Den Dunnen, J.T., Antonarakis S.E., 2000. Mutation nomenclature extensions and suggestions to describe complex mutations: a discussion. Hum. Mutat. 15, 7-12.

Dos Santos, C., Essioux, L., Teinturier, C., Tauber, M., Goffin, V., Bougneres, P., 2004. A common polymorphism of the growth hormone receptor is associated with increased responsiveness to growth hormone. Nat. Genet. 36, 720-724.

Esteban, C., Audi, L., Carrascosa, A., Fernandez-Cancio, M., Perez-Arroyo, A., Ulied, A., Andaluz, P., Arjona, R., Albisu, M., Clemente, M., Gussinye, M., Yeste, D., 2007. Human growth hormone (GH1) gene polymorphism map in a normalstatured adult population. Clin. Endocrinol. 66, 258-268.

Giordano, M., Marchetti, C., Chiorboli, E., Bona, G., Momigliano Richiardi, P., 1997. Evidence for gene conversion in the generation of extensive polymorphism in the promoter of the growth hormone gene. Hum. Genet. 100, 249-255.

Giordano, M., Godi, M., Giacopelli, F., Lessi, M., Mellone, S., Paracchini, R., Petri, A., Bellone, J., Ravazzolo, R., Bona, G., Momigliano-Richiardi, P., 2006. A variation in a Pit-1 site in the growth hormone gene $(G H 1)$ promoter induces a differential transcriptional activity. Mol. Cell. Endocrinol. 249, 51-57.

Giordano, M., Godi, M., Mellone, S., Petri, A., Vivenza, D., Tiradani, L., Carlomagno, Y., Ferrante, D., Arrigo, T., Corneli, G., Bellone, S., Giacopelli, F., Santoro, C., Bona, G., Momigliano-Richiardi, P., 2008. A functional common polymorphism in the vitamin D-responsive element of the $G H 1$ promoter contributes to isolated growth hormone deficiency. J. Clin. Endocrinol. Metab. 93, 1005-1012.

Hartman, M.L, Veldhuis, J.D., Johnson, M.L., Lee, M.M., Alberti, K.G., Samojlik, E., Thorner, M.O., 1992. Augmented growth hormone (GH) secretory burst frequency and amplitude mediate enhanced GH secretion during a two day fast in normal men. J. Clin. Endocrinol. Metab. 74, 757-765.

Hasegawa, Y., Fujii, K., Yamada, M., Igarashi, Y., Tachibana, K., Tanaka, T., Onigata, K., Nishi, Y., Kato, S., Hasegawa, T., 2000. Identification of novel human GH-1 gene polymorphisms that are associated with growth hormone secretion and height. J. Clin. Endocrinol. Metab. 85, 1290-1295. 
Ho, Y., Elefant, F., Cooke, N., Liebhaber, S., 2002. A defined locus control region determinant links chromatin domain acetylation with long-range gene activation. Mol. Cell 9, 291-302.

Horan, M., Millar, D.S., Hedderich, J., Lewis, G., Newsway, V., Mo, N., Fryklund, L., Procter, A.M., Krawczak, M., Cooper, D.N., 2003. Human growth hormone 1 (GH1) gene expression; complex haplotype-dependent influence of polymorphic variation in the proximal promoter and locus control region. Hum. Mut. 21, 408-423.

Horan, M., Newsway, V., Yasmin, Lewis, M.D., Easter, T.E., Rees, D.A., Mahto, A., Millar, D.S., Procter, A.M., Scanlon, M.F., Wilkinson, I.B., Hall, I.P., Wheatley, A., Blakey, J., Bath, P.M., Cockcroft, J.R., Krawczak, M., Cooper, D.N., 2006. Genetic variation at the growth hormone $(G H I)$ and growth hormone receptor $(G H R)$ loci as a risk factor for hypertension and stroke. Hum. Genet. 119, 527-540.

Jensen, RB., Vielwerth, S., Larsen, T., Greisen, G., Leffers, H., Juul, A., 2007. The presence of the $\mathrm{d} 3$-growth hormone receptor polymorphism is negatively associated with fetal growth but positively associated with postnatal growth in healthy subjects. J. Clin. Endocrinol. Metab. 92, 2758-2763.

Jones, B.K., Monks, B.R., Liebhaber, S.A., Cooke, N.E., 1995. The human growth hormone gene is regulated by a multicomponent locus control region. Mol. Cell. Biol. $15,7010-7021$.

Jorge, AA., Marchisotti, FG., Montenegro, LR., Carvalho, LR., Mendonca, BB., Arnhold, IJ., 2006. Growth hormone (GH) pharmacogenetics: influence of GH receptor exon 3 retention or deletion on first-year growth response and final height in patients with severe GH deficiency. J. Clin. Endocrinol. Metab. 91, 1076-1080.

Kaplan, S.L., 1999. Hormonal regulation of growth and metabolic effects of growth hormone. Chap. 5 in: Handbook of Physiology Section 7. The Endocrine System. Vol. V. Hormonal Control of Growth. Eds. J.L. Kostyo \& H.M. Goodman, pp129-143. Oxford University Press, New York.

Kenth, G., Shao, Z., Cole, D.E., Goodyer, C.G., 2007. Relationship of the human growth hormone receptor exon 3 genotype with final adult height and bone mineral density. J. Clin. Endocrinol. Metab. 92, 725-728.

Lewis, M.D., Horan, M., Millar, D.S., Newsway, V., Easter, T.E., Fryklund, L., Gregory, J.W., Norin, M., del Valle, C.-J., López-Siguero, J.P., López-Canti, L.P., Díaz-Torrado, N., Espino, R., Ulied, A., Scanlon, M.F., Procter, A.M., Cooper, D.N., 2004. A novel dysfunctional GH variant (Ile179Met) exhibits a decreased ability to activate the extracellular signal-regulated kinase (ERK) pathway. J. Clin. Endocrinol. Metab. 89, 1068-1075.

Luke, A., Cooper, R.S., Prewitt, T.E., Adeyemo, A.A., Forrester, T.E., 2001. Nutritional consequences of the African diaspora. Annu. Rev. Nutr. 21, 47-71. 
Matsubara, M., Omori, F., Fujita, S., Metoki, H., Kikuya, M., Fujiwara, T., Araki, T., Imai, Y., 2001. Haplotypes of aldosterone synthase (CYP11B2) gene in the general population of Japan: the Ohasama study. Clin. Exp. Hypertens. 23, 603-610.

Millar, D.S., Lewis, M.D., Horan, M., Newsway, V., Easter, T.E., Gregory, J.W., Fryklund, L., Norin, M., Crowne, E.C., Davies, S.J., Edwards, P., Kirk, J., Waldron, K., Smith, P.J., Phillips, J.A. III, Scanlon, M.F., Krawczak, M., Cooper, D.N., Procter, A.M., 2003. Novel mutations of the growth hormone 1 ( $G H 1)$ gene disclosed by modulations of the clinical selection criteria for individuals with short stature. Hum. Mut. 21, 424-440.

Miyata, I., Cogan, J.D., Prince, M.A., Kamijo, T., Ogawa, M., Phillips, J.A. III, 1997. Detection of growth hormone gene defects by dideoxyfingerprinting (ddF). Endocr. J. $44,149-154$.

Nørrelund, H., 2005. The metabolic role of growth hormone in humans with particular reference to fasting. Growth Horm. IGF. Res. 15, 95-122.

Ogasawara, K., Yabe, R., Uchikawa, M., Nakata, K., Watanabe, J., Takahashi, Y., Tokunaga, K., 2001. Recombination and gene conversion-like events may contribute to ABO gene diversity causing various phenotypes. Immunogenetics 53, 190-199.

Ohta, T., 1999. Effect of gene conversion on polymorphic patterns at major histocompatibility complex loci. Immunol. Rev. 167, 319-325.

Pantel, J., Machinis, K., Sobrier, M.L., Duquesnoy, P., Goossens, M., Amselem, S., 2000. Species-specific alternative splice mimicry at the growth hormone receptor locus revealed by the lineage of retroelements during primate evolution. J. Biol. Chem. 275, 18664-18669.

Parra, E.J., Marcini, A., Akey, J., Martinson, J., Barter, M.A., Cooper, R., Forrester, T., Allison, D.B., Deka, R., Ferrell, R.E., Shriver, M.D., 1998. Estimating African American admixture proportions by use of population-specific alleles. Am. J. Hum. Genet. 63, 1839-1851.

Pepe, G., Vanegas, O.C., Rickards, O., Giusti, B., Comeglio, P., Brunelli, T., Marcucci, R., Prisco, D., Gensini, G.F., Abbate, R., 1999. World distribution of the T833C/844INS68 CBS in cis double mutation: a reliable anthropological marker. Hum. Genet. 104, 126-129.

Pilotta, A., Mella, P., Filisetti, M., Felappi, B., Prandi, E., Parrinello, G., Notarangelo, L.D., Buzi, F., 2006. Common polymorphisms of the growth hormone (GH) receptor do not correlate with the growth response to exogenous recombinant human GH in GH-deficient children. J. Clin. Endocrinol. Metab. 91, 1178-1180.

Räz, B., Janner, M., Petkovic, V., Lochmatter, D., Eblé, A., Dattani, M.T., Hindmarsh, P.C., Flück, C.E., Mullis, P.E., 2008. Influence of growth hormone receptor $\mathrm{d} 3$ and full-length isoforms on growth hormone response and final height in patients with severe growth hormone deficiency. J. Clin. Endocrinol. Metab. 93: 974980. 
Ross, R.J., Esposito, N., Shen, X.Y., von Laue, S., Chew, S.L., Dobson, P.R., PostelVinay, M.C., Finidori, J., (1997) A short isoform of the human growth hormone receptor functions as a dominant negative inhibitor of the full-length receptor and generates large amounts of binding protein. Mol. Endocrinol. 11, 265-273.

Sedman, L., Padhukasahasram, B., Kelgo, P., Laan, M., 2008. Complex signatures of locus-specific selective pressures and gene conversion on human growth hormone/chorionic somatomammotropin genes. Hum. Mut. In press.

Seoane, S., Alonso, M., Segura, C., Pérez-Fernández, R., 2002. Localization of a negative vitamin $\mathrm{D}$ response sequence in the human growth hormone gene. Biochem. Biophys. Res. Commun. 292, 250-255.

Shewchuk, B.M., Asa, S.L., Cooke, N.E., Liebhaber, S.A., 1999. Pit-1 binding sites at the somatotrope-specific DNase I hypersensitive sites I, II of the human growth hormone locus control region are essential for in vivo hGH-N gene activation. J. Biol. Chem. 274, 35725-35733.

Shewchuk, B.M., Liebhaber, S.A., Cooke, N.E., 2002. Specification of unique Pit-1 activity in the hGH locus control region. Proc. Natl. Acad. Sci. USA 99, 1178411789.

Su, Y., Liebhaber, S.A., Cooke, N.E., 2000. The human growth hormone gene cluster locus control region supports position-independent pituitary- and placenta-specific expression in the transgenic mouse. J. Biol. Chem. 275, 7902-7909.

Tauber, M., Ester, W., Auriol, F., Molinas, C., Fauvel, J., Caliebe, J., Nugent, T., Fryklund, L., Ranke, MB., Savage, MO., Clark, AJ., Johnston, LB., Hokken-Koelega, AC., NESTEGG Group., 2007. GH responsiveness in a large multinational cohort of SGA children with short stature (NESTEGG) is related to the exon 3 GHR polymorphism. Clin. Endocrinol. (Oxf). 67, 457-461.

Thimmarayappa, J., Sun, J., Schultz, L.E., Dejkhamron, P., Lu, C., Giallongo, A., Merchant, J.L., Menon, R.K., 2006. Inhibition of growth hormone receptor gene expression by saturated fatty acids: role of Kruppel-like zinc finger factor, ZBP-89. Mol. Endocrinol. 20, 2747-2760.

Waters, M.J., Hoang, H.N., Fairlie, D.P., Pelekanos, R.A., Brown, R.J., 2006. New insights into growth hormone action. J. Mol. Endocrinol. 36, 1-7.

Wolf, A., Millar, D.S., Caliebe, A., Horan, M., Newsway, V., Kumpf, D., Steinmann, K., Chee, I.-S., Lee, Y.-H., Mutirangura, A., Pepe, M., Rickards, O., Schmidtke, J., Schempp, W., Chuzhanova, N., Kehrer-Sawatzki, H., Krawczak, M., Cooper, D.N., 2008. A gene conversion hotspot in the human growth hormone $(G H 1)$ gene promoter. Hum. Mut. In press.

Wright, N.M., Renault, J., Filli, S., Veldhuis, J.D., Pandey, J.P., Gordon, L., Key, L.L., Bell, N.H., 1995. Greater secretion of growth hormone in black than in white 
men: possible factor in greater bone mineral density - a clinical research center study.

J. Clin. Endocrinol. Metab. 80, 2291-2297. 


\section{Figure legends}

Fig. 1 A $G H 1$ gene conversion identified in the Beninese population. The promoter sequence differs from the wild-type $G H 1$ gene sequence at five nucleotide positions between -39 and 53 where it corresponds precisely to the sequence of the paralogous $\mathrm{CSH} 1$ and $\mathrm{CSH} 2$ genes.

The vitamin D response element (Alonso et al., 1998; Seoane et al., 2002) in the human GH1 gene is marked in bold.

Fig.2. GHR exon 3 deletion (d3) polymorphism genotype frequencies in the Beninese (hatched bars) and British (solid bars) populations. 


\section{Figure 1.}

GH1

GH1 gene conversion

CSH1/CSH2

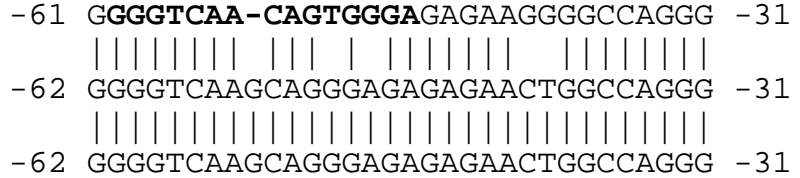


Figure 2.

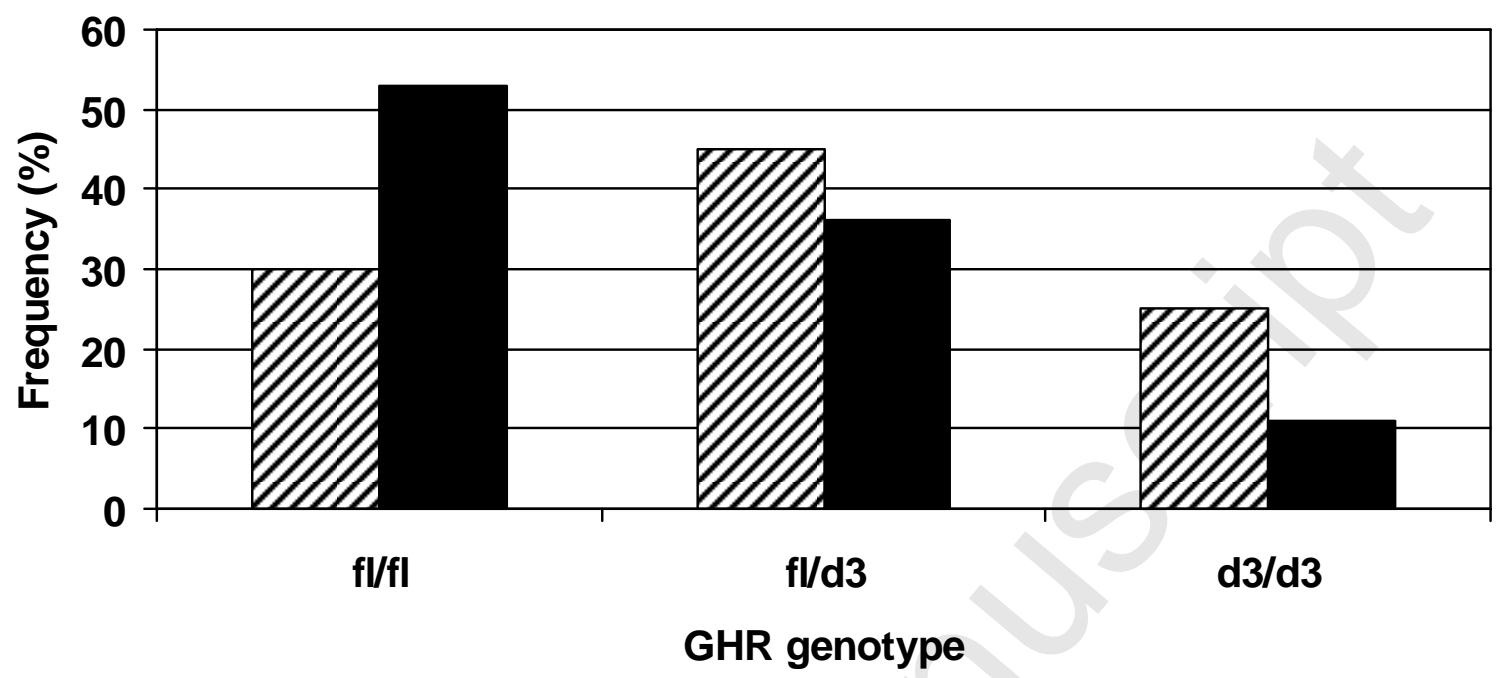


Table 1. Location and frequency of $G H 1$ variants occurring in the Beninese population sample at a frequency of $>1 \%$

\begin{tabular}{|c|c|c|c|}
\hline Variant $^{\mathrm{a}, \mathrm{b}}$ & Entrez SNP & Location & $\begin{array}{l}\text { Allele } \\
\text { frequency }(\%)\end{array}$ \\
\hline delCT $-525 /-526$ & - & Promoter & 2.2 \\
\hline A-360G & rs61761357 & Promoter & 13.5 \\
\hline $\mathrm{T}-352 \mathrm{G}$ & - & Promoter & +8 \\
\hline G-261C & rs61761358 & Promoter & $\Delta=$ \\
\hline $\mathrm{C}-227 \mathrm{~T}$ & - & Promoter & 8.9 \\
\hline Gene conversion $^{\mathrm{c}}$ & - & Promoter/5' UTR & 5.5 \\
\hline$A+10 G$ & - & 5'UTR & $6.1 \bigcirc$ \\
\hline A+69G (Thr3Ala $\left.{ }^{\mathrm{d}}\right)^{\mathrm{e}, \mathrm{f}}$ & rs2001345 & Exon 1 & 11.0 \\
\hline $\mathrm{G}+140 \mathrm{~A}$ & - & Intron 1 & 1.2 \\
\hline $\mathrm{G}+144 \mathrm{~A}$ & - & Intron 1 & 1.2 \\
\hline $\mathrm{G}+192 \mathrm{C}$ & rs2001344 & Intron 1 & 12.9 \\
\hline $\mathrm{T}+281 \mathrm{C}^{\mathrm{e}}$ & rs3744287 & Intron 1 & 3.4 \\
\hline $\mathrm{C}+438 \mathrm{~T}$ (Ala13Val) & - & Exon 2 & 5.2 \\
\hline C+472A (Ala24Ala) & - & Exon 2 & 1.2 \\
\hline T+474A (Phe25Tyr) & - & Exon 2 & 1.2 \\
\hline $\mathrm{C}+596 \mathrm{~T}$ & rs57431470 & Intron 2 & 1.8 \\
\hline T+986A (Ser95Arg) & - & Exon 4 & 2.2 \\
\hline G+1070A (Thr123Thr) & rs41295043 & Exon 4 & 2.8 \\
\hline $\mathrm{G}+1098 \mathrm{~T}$ & rs61735351 & Intron 4 & 5.2 \\
\hline $\mathrm{G}+1136 \mathrm{~A}$ & rs61735352 & Intron 4 & 4.9 \\
\hline $\mathrm{T}+1169 \mathrm{~A}^{\mathrm{e}, \mathrm{g}}$ & rs2665802 & Intron 4 & 3.1 \\
\hline $\mathrm{G}+1215 \mathrm{~A}$ & rs61735355 & Intron 4 & 1.8 \\
\hline $\mathrm{T}+1231 \mathrm{~A}$ & rs61735356 & Intron 4 & 1.5 \\
\hline $\operatorname{del} A+1246$ & - & Intron 4 & 1.2 \\
\hline
\end{tabular}

${ }^{\mathrm{a}}$ Nomenclature recommended by den Dunnen and Antonarakis (2000)

${ }^{\mathrm{b}}$ Numbering relative to the transcription initiation site at +1 (GenBank accession number J03071)

${ }^{\mathrm{c}}$ Gene conversion to $\mathrm{CSH} 1$ (minimum -53 to -39 ; maximum -112 to +9 ) or $\mathrm{CSH} 2$ sequence (minimum -53 to -39 ; maximum -123 to +9 )

${ }^{\mathrm{d}}$ Previously termed Thr-24Ala by ourselves and others

${ }^{\mathrm{e}}$ Previously identified in the European population (Esteban et al., 2007)

${ }^{\mathrm{f}}$ Previously identified in the Japanese population (Miyata et al., 1997)

${ }^{\mathrm{g}}$ Previously identified in the Japanese population (Hasegawa et al., 2000) 
Table 2. GH1 promoter haplotypes (as defined by Horan et al., 2003) found in the Beninese population: in vitro expression assay data and population frequencies

\begin{tabular}{|c|c|c|c|c|}
\hline Haplotype & Haplotype $^{\mathrm{a}}$ & Luciferase & Benin & European $^{\mathrm{b}}$ \\
\hline acronym & & activity \pm SEM & $n=326(\%)$ & $n=606(\%)$ \\
\hline $\mathrm{H} 1$ & GGGGGGTATGAAGAAT & $100.0 \pm 2.3$ & $85(26.0)$ & $191(31.5)$ \\
\hline $\mathrm{H} 8$ & GGGTTGTAGGGAGAAT & $103.0 \pm 9.8$ & $51(15.6)$ & $17(2.8)$ \\
\hline $\mathrm{H} 23$ & GGGGGGTAGGAAGAAT & $33.0 \pm 3.2$ & $32(9.8)$ & $5(0.8)$ \\
\hline $\mathrm{H} 42$ & GGGGGGTAGGACCAAG & $98.7 \pm 11.1$ & $23(7.0)$ & - \\
\hline $\mathrm{H} 43$ & GGGGGGTATGGTGAAT & $135.3 \pm 17.8$ & $18(5.5)$ & - \\
\hline $\mathrm{H} 44$ & GGGTTGTAGGACCAAT & $135.2 \pm 12.5$ & $15(4.6)$ & - \\
\hline $\mathrm{H} 35$ & GGGGGGTAGGACCAAT & $83.6 \pm 8.0$ & $13(3.9)$ & $2(0.3)$ \\
\hline $\mathrm{H} 45$ & GGGGGGTAGGGAGGAT & $138.8 \pm 11.5$ & $11(3.3)$ & - \\
\hline $\mathrm{H} 2$ & GGGGGTTAGGGAGAAT & $97.2 \pm 9.5$ & $9(2.7)$ & $91(15.0)$ \\
\hline $\mathrm{H} 7$ & GGGGGTTAGGGTGAAT & $61.1 \pm 3.6$ & $9(2.7)$ & $13(2.1)$ \\
\hline $\mathrm{H} 46$ & GT-GGGTATGGAGAAT & $136.7 \pm 13.1$ & $7(2.1)$ & - \\
\hline $\mathrm{H} 47$ & GT-GGGTAGGGAGAAT & $119.9 \pm 12.2$ & $5(1.5)$ & - \\
\hline $\mathrm{H} 48$ & GGGTTGTGGGACCAAT & $77.6 \pm 6.5$ & $5(1.5)$ & $2(0.3)$ \\
\hline $\mathrm{H} 49$ & GG-GGTTAGGGTGAAT & $111.1 \pm 9.0$ & $5(1.5)$ & - \\
\hline $\mathrm{H} 50$ & GGGGGGTAG-ACCAAG & $129.9 \pm 12.1$ & $4(1.2)$ & - \\
\hline H51 & GGGGGGTAGGGAGAAT & $133.0 \pm 14.4$ & $4(1.2)$ & - \\
\hline $\mathrm{H} 3$ & GGGTTGTAGGAAGAAT & $37.1 \pm 3.3$ & $3(0.9)$ & $41(6.8)$ \\
\hline $\mathrm{H} 17$ & GG-GGTTAGGGAGAAT & $54.6 \pm 3.1$ & $3(0.9)$ & $6(1.0)$ \\
\hline H52 & GGGGGGTAG-ACCAAT & $121.9 \pm 13.8$ & $3(0.9)$ & - \\
\hline $\mathrm{H} 20$ & GGGGGGTAG-AAGAAT & $75.6 \pm 5.0$ & $2(0.6)$ & $3(0.5)$ \\
\hline $\mathrm{H} 53$ & GGGGGGTAGGGTGAAT & $119.8 \pm 14.5$ & $2(0.6)$ & - \\
\hline H54 & GGGTTGTGGGGAGAAT & $85.1 \pm 13.2$ & $2(0.6)$ & - \\
\hline $\mathrm{H} 15$ & GGGTTGTAGGGTGAAT & $59.6 \pm 5.2$ & $1(0.3)$ & $12(2.0)$ \\
\hline $\mathrm{H} 22$ & GGGTTGTATGAAGAAT & $100.4 \pm 8.1$ & $1(0.3)$ & $3(0.5)$ \\
\hline $\mathrm{H} 55$ & GGGGGGTATGATGAAT & $135.3 \pm 4.9$ & $1(0.3)$ & - \\
\hline H56 & GGGGGGTGGGGAGAAT & $81.5 \pm 4.5$ & $1(0.3)$ & - \\
\hline $\mathrm{H} 57$ & GGGGGTTAGGACCAAT & $134.0 \pm 10.6$ & $1(0.3)$ & $1(0.2)$ \\
\hline H58 & GGGGGTTAGGGCCAAT & $152.8 \pm 13.1$ & $1(0.3)$ & - \\
\hline $\mathrm{H} 59$ & GGGGGGTGTGAAGAAT & $169.8 \pm 13.8$ & $1(0.3)$ & - \\
\hline H60 & GT-GGGTAG-GAGAAT & $136.5 \pm 6.2$ & $1(0.3)$ & - \\
\hline H61 & GGGTTGTAGGACCAAG & $111.0 \pm 9.1$ & $1(0.3)$ & - \\
\hline H62 & GGGGGGTAGGACCGCG & $130.3 \pm 5.3$ & $1(0.3)$ & - \\
\hline H63 & GGGGGGTAGGGCCAAG & $124.0 \pm 4.6$ & $1(0.3)$ & - \\
\hline H64 & GGGGGGTAGGGAGGAG & $122.5 \pm 6.9$ & $1(0.3)$ & - \\
\hline H65 & GT-TTGTAGGGAGAAT & $140.1 \pm 10.7$ & $1(0.3)$ & - \\
\hline H66 & GGGGGGTGGGACCAAT & $94.0 \pm 5.3$ & $1(0.3)$ & - \\
\hline H67 & GGGGGGTAG-GTGAAT & $118.0 \pm 7.7$ & $1(0.3)$ & $1(0.2)$ \\
\hline
\end{tabular}

${ }^{\mathrm{a}}$ order of SNPs as described in Table 1 of Horan et al., (2003) and Supplementary Table 2.

${ }^{\mathrm{b}}$ Haplotypes identified in Europeans (Horan et al., 2003; Lewis et al. 2004; unpublished results). NB. Only 388 of the 606 haplotypes (64.0\%) are listed; the remaining European haplotypes were not found in the Beninese population sample. 
Table 3. Analysis of functional activity and secretion in vitro of GH coding sequence variants

\begin{tabular}{|l|l|l|l|l|l|l|l|l|}
\hline & \multicolumn{4}{|l|}{ GH function $\left(\mathrm{EC}_{50}\right)$} & \multicolumn{4}{l|}{ GH secretion } \\
\hline Variant & $\mathrm{EC}_{50} \mathrm{nM}$ & $\mathrm{SEM}$ & $\mathrm{n}$ & $\mathrm{p}^{\mathrm{a}}$ & Mean $\%$ & SEM & $\mathrm{n}$ & $\mathrm{p}^{\mathrm{a}}$ \\
\hline Wild-type $^{\mathrm{b}}$ & 2.98 & 0.41 & 6 & - & 100 & 13 & 4 & - \\
\hline Ala13Val & 2.43 & 0.09 & 3 & $\mathrm{~ns}$ & 87 & 5 & 4 & $\mathrm{~ns}$ \\
\hline Arg19His & 3.77 & 0.64 & 3 & $\mathrm{~ns}$ & 74 & 5 & 4 & $\mathrm{~ns}$ \\
\hline Phe25Tyr & 2.85 & 0.45 & 3 & $\mathrm{~ns}$ & 77 & 3 & 4 & $\mathrm{~ns}$ \\
\hline Ser95Arg & 3.90 & 0.22 & 3 & $\mathrm{~ns}$ & 125 & 5 & 4 & $\mathrm{~ns}$ \\
\hline
\end{tabular}

${ }^{a} \mathrm{p}$ values from a comparison with wild-type using ANOVA.

${ }^{\mathrm{b}}$ wild-type refers to GH variant 1 protein (accession number NP_000506). ns: not significant. SEM: Standard error of the mean.

Mean \%: mean calculated as a percentage of the average wild-type value.

$\mathrm{EC}_{50} \mathrm{nM}$ is the median effective concentration (required to induce a $50 \%$ effect). 
Table 4. Luciferase reporter gene assay-based expression activity of different combinations of haplotype 43 with the gene conversion and A+10G sequence variants

\begin{tabular}{|l|l|l|l|l|}
\hline & Mean & SEM & $\mathrm{n}$ & $\mathrm{p}^{\mathrm{a}}$ \\
\hline H43 & 1.000 & 0.056 & 18 & - \\
\hline H43 and gene conversion (H43GC) & 1.744 & 0.100 & 18 & $<0.0001$ \\
\hline H43 and A+10G (H43+10G) & 0.805 & 0.058 & 18 & 0.022 \\
\hline $\begin{array}{l}\text { H43 and gene conversion and A+10G } \\
\text { (H43GC+10G) }\end{array}$ & 1.325 & 0.047 & 18 & $<0.0001$ \\
\hline
\end{tabular}

${ }^{\mathrm{a}} \mathrm{p}$ values from a comparison with haplotype H43 using a Student t-test. 